\title{
Effects of different silvicultural measures on plant diversity - the case of the Illyrian Fagus sylvatica habitat type (Natura 2000)
}

\author{
Lado Kutnar ${ }^{(1)}$, Klemen Eler ${ }^{(1-2)}$, \\ Aleksander Marinšek ${ }^{(1-3)}$
}

\begin{abstract}
In Slovenia, the Natura 2000 network covers more than $37 \%$ of the country. Forests dominate more than $70 \%$ of this area, and forest management is a significant driver of diversity. Depending on the options applied, forest management may enhance or decrease forest biodiversity. Dinaric fir-beech forests (part of Natura $\mathbf{2 0 0 0}$ habitat type) with remarkable nature-conservation interest and timber production functions were selected for this study. With the aim of testing the effects of different silvicultural measures on plant diversity in these forests, and consequently on biodiversity in a broader sense, three sites in the Slovenian part of a Dinaric fir-beech forest range were studied. The plant species diversity was assessed before and after the implementation of silvicultural measures of three intensities: (1) control plots - no logging; (2) logging of $50 \%$ of the growing stock; and (3) logging of $100 \%$ of the growing stock. Before the implementation of the silvicultural measures, the mean number of plant species per $400 \mathrm{~m}^{2}$ vegetation plots was 48.8 , and the mean value of the Shannon's diversity index was 2.41 . Two years after the measures were implemented, different magnitudes of plant species turnover were observed. There were no significant changes in plant diversity status and vegetation composition in the control plots. Two years after $50 \%$ of the growing stock was logged, the mean number of species was 73.3 , and the mean value of the Shannon index was 3.21. In the plots where all the trees were removed, the mean number of species was 87.4, and the mean value of the Shannon index was 3.42. In parallel with the increases in the diversity parameters, the cover of the herbaceous layer increased significantly with an increase in the silvicultural intensity, indicating that short-term species turnover can mostly be attributed to herbaceous plant species. As a result of changed stand and ecological conditions, an increased plant diversity, a greater biodiversity in a broader sense and an improved habitat suitability for different animal species could be expected.
\end{abstract}

Keywords: Forest Management, Silviculture, Nature Conservation, Plant Diversity, Species Turnover, Gap Colonization, Mountain Forest, Dinaric Fir-beech Forest, Natura 2000

measures. Forest management is one of the primary drivers of diversity and, according to the applied measures, may act as a factor of enhancement or reduction of biodiversity. Appropriate management options need to be tested and implemented, especially within the managed forests with significant biodiversity value.
(1) Slovenian Forestry Institute, Department of Forest Ecology, Večna pot 2, SI-1000 Ljubljana (Slovenia); (2) Biotechnical Faculty, University of Ljubljana, Jamnikarjeva 101, SI-1000 Ljubljana (Slovenia); (3) Higher Vocational College for Forestry and Hunting, Ljubljanska 3, SI-6230 Postojna (Slovenia)

@ Lado Kutnar (lado.kutnar@gozdis.si)

Received: Feb 04, 2015 - Accepted: Jul 08, 2015

Citation: Kutnar L, Eler K, Marinšek A (2015). Effects of different silvicultural measures on plant diversity - the case of the Illyrian Fagus sylvatica habitat type (Natura 2000). iForest 9 : 318-324. - doi: 10.3832/ifor1587-008 [online 2015-10-22]

Communicated by: Renzo Motta
Generally, the overall biodiversity of a forested area is dependent on the biodiversity of individual communities and the spatial heterogeneity of the area. In this respect, the measures can be targeted to either of these two levels. Spatial heterogeneity can be significantly increased by gap formation and other similar silvicultural options.

Among the most significant nature-conservation efforts in Europe is Natura 2000, which is a coherent ecological network of special areas. Nearly $50 \%$ of Natura 2000 habitats are forests, and approximately $23 \%$ of all EU forests are located within Natura 2000 sites (EC 2014). Natura 2000 has been designated under the EU Habitats Directive (1992) and EU Birds Directive (1979) to assist in the maintenance of biodiversity on European territory and to preserve biodiversity and habitats in a favorable conservation status. It is widely recognized that the most effective way of maintaining biodiversity is to preserve habitats in a favorable conservation status (Cantarello \& 


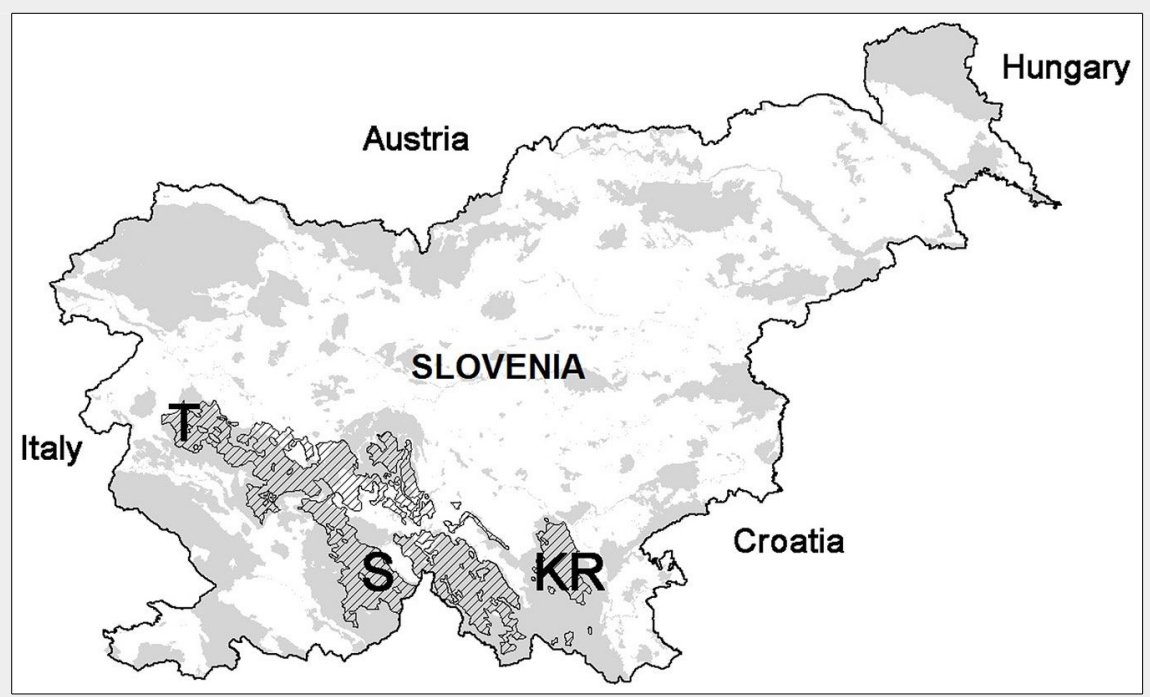

Fig. 1 - Selected sites (Kočevski Rog, KR; Snežnik, S; and Trnovo, T) within Dinaric firbeech forests (hatch). Natura 2000 areas are indicated in grey.

Newton 2008a, 2008b). However, the Directives and Natura 2000 do not provide a framework for practical management actions to be applied to each habitat type and species. The implementation of Natura 2000 in forests has led to conflicts related to different interests and land use paradigms, e.g., balancing nature conservation and sustainable timber production (Niemelä et al. 2005, Bouwma et al. 2010). However, forest management performed in a sustainable manner could even contribute to increasing biodiversity (Lindenmayer et al. 2000).

Dinaric forests of European beech (Fagus sylvatica) and European silver fir (Abies alba - hereafter referred to as Dinaric firbeech forests; the Latin name of this association is Omphalodo-Fagetum s. lat.) are an example in which possible conflicting interests may occur. These forests are close-tonature managed, which means that the forest management and its intensity must be carefully adjusted to the specific functions and goals set for these Dinaric fir-beech forests, including biodiversity conservation. Dinaric fir-beech forests are one of the most extensive forest communities within Natura 2000 in this part of Europe, and also one of the most widespread forest types in Slovenia. They account for more than $10 \%$ of the Slovenian forest area (Dakskobler 2008) and belong to the 91KoIllyrian Fagus sylvatica (Aremonio-Fagion) habitat type of Natura 2000 (Kutnar et al. 2011). This habitat type includes different forests of European beech growing in the Dinaride range and in associated ranges and hills, with outliers in the southeastern Alps, in the southwestern Carpathians and in the mid-Pannonian hills. In these ecosystems, species diversity is greater than in the central European beech forests, and the beech forests of the Aremonio-Fagion alliance are an important source of species diversity (EC 2007).
The main efforts of modern silviculture focus on the balanced use of forest ecosystem resources (Siry et al. 2005). Attempts to achieve this are performed by mimicking naturally-occurring processes in forest ecosystems (Gamborg \& Larsen 2003). However, it is not well known to what extent the close-to-nature silvicultural system improves the stability of the forest ecosystem in terms of biodiversity (Durak 2012). Within this array of close-to-nature alternatives, different silvicultural options may be implemented, and different effects on forest ecosystem functioning are expected according to the type of management used (Decocq et al. 2004, 2005, Schmidt 2005). Therefore, it is crucial to determine the outcomes of different types and intensities of silvicultural practices.

The main objective of this study was to test the effects of different silvicultural measures on plant species diversity in $\mathrm{Di}$ naric fir-beech forests (a part of Natura 2000 Illyrian Fagus sylvatica habitat type). In these close-to-nature managed forests with predominantly closed stands, we aimed to provide information on vegetation development after the implementation of innovative silvicultural practices and to discuss a possible contribution to biodiversity in a broader sense.

\section{Materials and methods}

\section{Study area and site selection}

Three test sites were selected in the Dinaric fir-beech forests of Slovenia (Kočevski Rog, KR; Snežnik, S; and Trnovo, T - Fig. 1, Tab. 1). These forests thrive at high altitude karst areas (700-1200 $\mathrm{m}$ a.s.l.) with diverse soil and climate conditions, which are highly favorable due to abundant rainfall and high air humidity. Different processes in the previous 40 years, such as silver fir decline and forest management supporting uneven-aged stands, have created high variability in the forest structure (Kobal \& Hladnik 2009).

European beech, European silver fir and Norway spruce (Picea abies) were dominant in all three study sites. Other tree species (mostly in the understory layer) included sycamore maple (Acer pseudoplatanus), wych elm (Ulmus glabra), common ash (Fraxinus excelsior), rowan (Sorbus aucuparia), small-leaved and large-leaved lindens (Tilia cordata, T. platyphyllos), manna ash (Fraxinus ornus), whitebeam (Sorbus aria), Norway and Bosnian maples (Acer platanoides, A. obtusatum), and common aspen (Populus tremula).

\section{Experimental design}

An area of karst depressions (sinkholes) was preselected at each test site. Among all preselected sinkholes, nine were randomly chosen at each test site, and circular plots of 0.4 ha were established at the bottom of sinkholes (27 plots in total). At the beginning of the experiment, the stands in the sinkholes were relatively dense.

To test the effects of forest management, three different silvicultural measures were implemented in the selected plots in 2012. In one third of all plots ( 3 per site), all trees in the area (100\% of the growing stock) were cut. In another one third of all plots, $50 \%$ of the growing stock was cut, using a single-tree selection silvicultural system aimed at preserving candidate trees with desirable properties (e.g., healthy, stable, desirable species, straight stem, regeneration potential). The tree species composition of candidate trees followed the current management goals according to the forest management plan. The spatial distribution of the selected candidate trees was homogeneous across the plot area. The selected candidate trees were promoted by removal of their competitors with less desirable properties. The diameters at breast height of the cut trees were at least 10 centimeters. Immediately after tree logging in two thirds of the plots, logs and thick branches were removed from the logging sites and skidded to a landing. No logging was conducted in one third of the plots, and these plots were kept as control plots.

\section{Vegetation survey}

The plant species diversity was assessed before and two years after the implementation of the silvicultural measures described above. Overall, 27 circular vegetation plots of $400 \mathrm{~m}^{2}$ were established in the central/bottom part of the selected sinkhole. In each vegetation plot, cover estimation of different vertical vegetation layers and plant species diversity were assessed according to the modified ICP-Forests protocol (Canullo et al. 2011). Furthermore, the percentage cover of each vegetation layer, the proportion of bare soil and surface rocks were assessed in the plots based on visual inspection.

All vascular plant species were recorded 
Tab. 1 - Characteristics of the three study sites.

\begin{tabular}{|c|c|c|c|}
\hline Study site & Kočevski Rog (KR) & Snežnik (S) & Trnovo (T) \\
\hline Position & $\begin{array}{l}\text { south-eastern Slovenia; } \\
45.668^{\circ} \mathrm{N}, 15.033^{\circ} \mathrm{E}\end{array}$ & $\begin{array}{l}\text { southern Slovenia; } \\
45.672^{\circ} \mathrm{N}, 14.460^{\circ} \mathrm{E}\end{array}$ & $\begin{array}{l}\text { western Slovenia; } \\
45.989^{\circ} \mathrm{N}, 13.759^{\circ} \mathrm{E}\end{array}$ \\
\hline Elevation & 831-902 m a.s.l. & $753-815 \mathrm{~m}$ a.s.l. & $801-869 \mathrm{~m}$ a.s.l. \\
\hline Area & approximately 70 ha & approximately $70 \mathrm{ha}$ & approximately 70 ha \\
\hline Relief & $\begin{array}{l}\text { high karst range with diverse terrain } \\
\text { with numerous sinkholes, ridges, and } \\
\text { slopes }\end{array}$ & $\begin{array}{l}\text { high karst range with diverse } \\
\text { terrain with numerous sinkholes, } \\
\text { ridges, and slopes }\end{array}$ & $\begin{array}{l}\text { high karst plateau with diverse } \\
\text { terrain with numerous sinkholes, } \\
\text { ridges, and slopes }\end{array}$ \\
\hline Geology and soil & $\begin{array}{l}\text { limestone and dolomite; leptosols, } \\
\text { cambisols and luvisols }\end{array}$ & $\begin{array}{l}\text { limestone and dolomite; } \\
\text { leptosols, cambisols and luvisols }\end{array}$ & $\begin{array}{l}\text { limestone and dolomite; } \\
\text { leptosols, cambisols and luvisols }\end{array}$ \\
\hline $\begin{array}{l}\text { Mean annual precipitation, } \\
\text { 1971-2000 (ARSO 2014) }\end{array}$ & approximately $1700 \mathrm{~mm}$ & approximately $1700 \mathrm{~mm}$ & approximately $2000 \mathrm{~mm}$ \\
\hline $\begin{array}{l}\text { Mean annual temperature, } \\
1971-2000 \text { (ARSO 2014) }\end{array}$ & $8^{\circ} \mathrm{C}$ & $8^{\circ} \mathrm{C}$ & $9^{\circ} \mathrm{C}$ \\
\hline Forest type & uneven-aged Dinaric fir-beech forests & $\begin{array}{l}\text { uneven-aged Dinaric fir-beech } \\
\text { forests }\end{array}$ & $\begin{array}{l}\text { uneven-aged Dinaric fir-beech } \\
\text { forests }\end{array}$ \\
\hline $\begin{array}{l}\text { Growing stock (in the } \\
\text { whole Management unit) }\end{array}$ & approximately $350 \mathrm{~m}^{3} \mathrm{ha}^{\prime}{ }^{1}$ & more than $400 \mathrm{~m}^{3} \mathrm{ha}^{\prime}{ }^{1}$ & approximately $300 \mathrm{~m}^{3} \mathrm{ha}^{1}$ \\
\hline $\begin{array}{l}\text { Mean increment (in the } \\
\text { whole Management unit) }\end{array}$ & $9.4 \mathrm{~m}^{3} \mathrm{ha}^{\prime} \mathrm{yr}^{\prime}{ }^{1}$ & $8.3 \mathrm{~m}^{3} \mathrm{ha}^{\prime} \mathrm{yr}^{\prime}{ }^{1}$ & $6.2 \mathrm{~m}^{3} \mathrm{ha}^{\prime} \mathrm{yr}^{\prime}{ }^{1}$ \\
\hline $\begin{array}{l}\text { Forest management } \\
\text { history }\end{array}$ & $\begin{array}{l}\text { First forest management plan devised } \\
\text { by Hufnagel (1892) introduced close-to- } \\
\text { nature management and suspended } \\
\text { clear-cutting; some virgin forest } \\
\text { remnants were protected in this region. }\end{array}$ & $\begin{array}{l}\text { Systematic and organized forest } \\
\text { management planning since the } \\
\text { beginning of the } 20^{\text {th }} \text { Century } \\
\text { (Schollmayer 1906). }\end{array}$ & $\begin{array}{l}\text { First forestry plans in the } 18^{\text {th }} \\
\text { century (Flamek } 1771 \text { ); } \\
\text { individual edicts for regulating } \\
\text { forests as early as the } 15^{\text {th }} \\
\text { century. }\end{array}$ \\
\hline
\end{tabular}

separately in three vertical layers (herb, shrub, and tree layer). A separate record was compiled for each species in the different vertical layers. The visual estimation of plant species cover was conducted using a modified Barkman's method (Barkman et al. 1964). Nomenclature of species names followed Mala Flora Slovenije (Martinčič et al. 2007) and Flora Europaea (Tutin et al. 1980, 1993).

\section{Data analysis}

Herb layer cover and diversity measures were assessed at plot and site levels before and two years after the silvicultural interventions. The following measures of diversity were calculated:

1. species richness $(N)$ as the number of species within a given plot;

2. Shannon diversity index $\left(H^{\prime}\right)$ is a measure that describes the structural composition of communities (Pielou 1975 - eqn. 1):

$$
H^{\prime}=\sum_{i=1}^{R} p_{i} \ln p_{i}
$$

where $p_{\mathrm{i}}$ is the relative cover of the $i$-th species in a record, and $R$ is the number of records in the data set considered.

Differences among treatments in herb cover, number of species and Shannon index were tested using linear mixed-effects models, using sampling plots as a random factor and silvicultural measures, location and sampling periods as fixed factors. Prior to the analysis, Levene's test was applied to each variable to check for variance homogeneity among treatments. After the overall model was tested, planned contrasts were applied to test for the differences between combinations of silvicultural measures and sampling periods (6 levels). All tests were conducted using the software package $R$ ( $R$ Core Team 2013) with $a=$ 0.05 .

The main compositional and diversity gradients of the study sites and plots were extracted by applying the detrended correspondence analysis (DCA - Hill \& Gauch 1980, McCune \& Grace 2002) using the software package PC-ORD version 6.0 (MCCune \& Mefford 2011). DCA is an eigenvector ordination technique based on correspondence analysis which ordinates both study plots/sites and plant species simultaneously, and is suitable to ecological-diversity data sets, i.e., the eigenvalues are related to the diversity and structural parameters in this case).

Based on the plant species composition before and after logging, the plots from three sites were plotted in a DCA ordination space. Differences between the plots and sites were indicated graphically.

\section{Results}

Before the implementation of the silvicultural measures, a total of 151 plant species were recorded in all vegetation plots. Two years after logging, a total of 250 plant species were identified. Six species from the first assessment were not confirmed again. In all vegetation plots, a total of 105 new plant species were recorded, mostly early successional species and non-typical forest plants. Among these, grasses, graminoid species from the Cyperaceae and Juncaceae families, and some species of the Fabaceae and Asteraceae families prevailed. The majority of these species appeared in the forest gaps created by high-intensity logging measures.

Before logging, the mean number of species per vegetation plot was 48.8 (varied between 29 and 68 per plot), and the Shannon diversity index $\left(H^{\prime}\right)$ was between 1.23 and 3.32 (mean: 2.41). After logging, the mean species number per vegetation plot was 70.4 (range: 41-106), and the index $H^{\prime}$ was between 2.04 and 3.81 (mean: 3.07).

Before the logging at selected sites, the tree canopy was dense and stands were closed; the mean cover value of the tree layer (based on visual estimation) was $95 \%$. Two years after logging, the mean cover of the tree layer was only $48 \%$, while tree cover in control plots remained almost the same as compared to the beginning of the experiment. Gaps opening in the canopy promoted changes in light conditions on the forest floor, which resulted in the development of a herb layer, including herb species, graminoids, and saplings of different woody plants. Before logging, the herb layer cover varied between $22 \%$ at the Snežnik site and $37 \%$ at the Trnovo site. Two years after logging, a significant increase in the herb layer cover was recorded, varying between $39 \%$ at the Snežnik site and $63 \%$ at the Trnovo site.

The highest mean species number before logging was recorded at the Snežnik site (55.8 species), and the lowest at the Trnovo site (43.1). Significant increases in the number of plant species after logging were recorded at all three sites. The mean species number per plot was the highest at the Snežnik site (78.1 species) and the lowest at the Kočevski Rog site (65.9 species). However, the highest relative change in mean species number was recorded at the Trnovo site, where $N$ increased by $56 \%$. The relative changes in the species number at the other two sites were 39\% (Kočevski Rog) and 40\% (Snežnik).

The mean Shannon diversity index before logging varied between 2.31 (Trnovo site) and 2.53 (Kočevski Rog). After logging, the mean $H^{\prime}$ increased by $19 \%$ at Kočevski Rog, 
Fig. 2 - Mean cover of the herb layer, the species number and the Shannon index for three silvicultural measures before (1) and two years after the logging (2) in the study plots at three sites (Kočevski Rog Snežnik and Trnovo). The error bars represent the standard errors of the mean. The letters denote homogeneous groups of treatments at a 0.05 significance level'means with the same letter are not significantly different from each other.
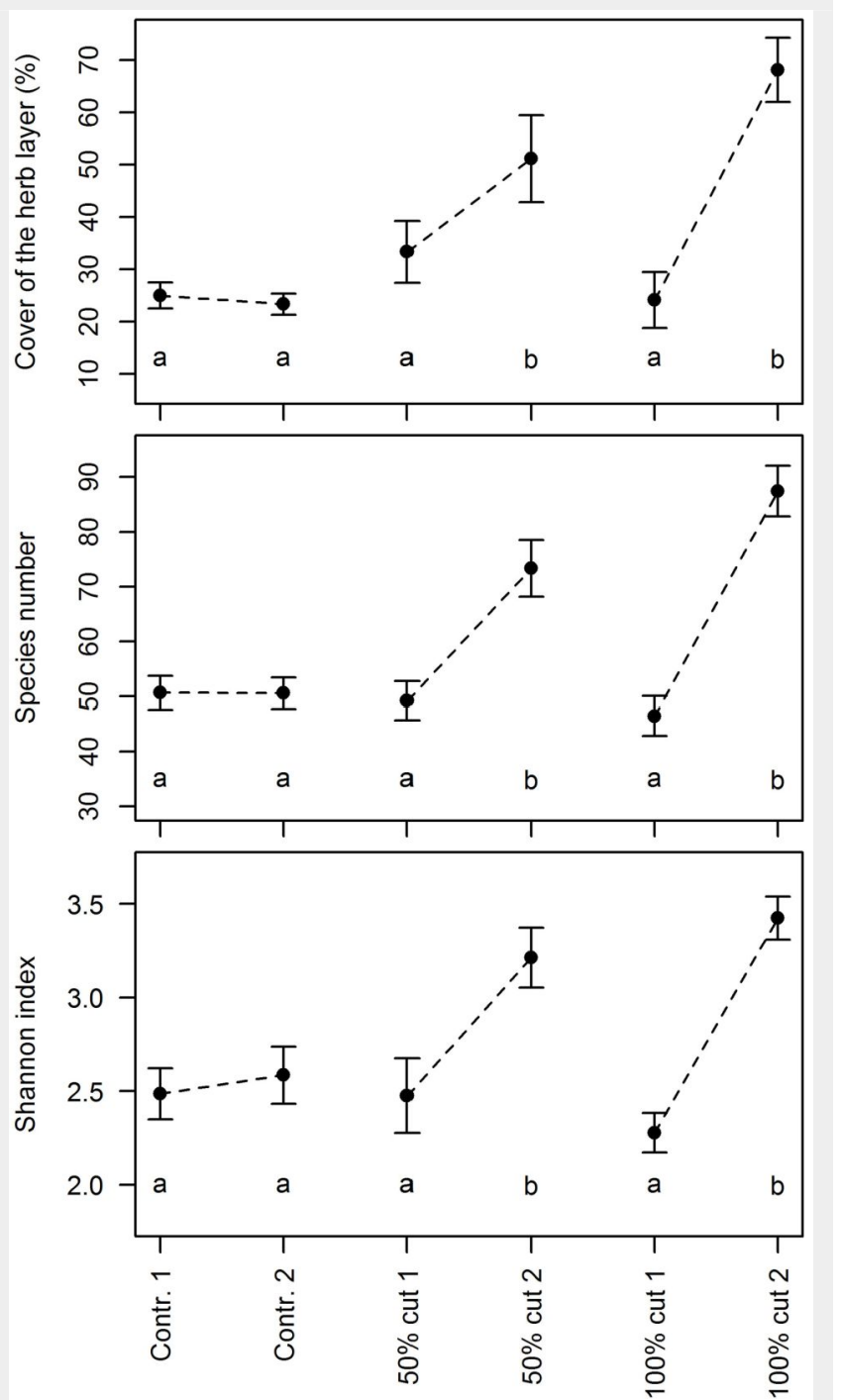

$38 \%$ at Snežnik and $26 \%$ at Trnovo, and varied between 2.91 (Trnovo) and 3.30 (Snežnik).

Different intensities of the implemented silvicultural measures had remarkably different effects on the studied parameters (Fig. 2). In the control plots, no significant changes in the herb layer cover and plant diversity were detected. In the plots where $50 \%$ of the growing stock was cut, the mean herb layer cover increased on average by $18 \%$, the mean number of species by 24 , and the mean value of the Shannon index by 0.74 . In the plots where all trees were removed, the mean herb layer cover increased by $44 \%$, the mean number of species by 41 , and the mean value of the Shannon index by 1.15; however, such figures did not differ significantly from the 50\% logging for any of the considered parameters (Fig. 2).

Based on plant species composition before and after logging, 27 study plots from the three test sites were plotted in the DCA ordination space in Fig. 3. Significant differences in species composition among the three sites at the beginning of the experiment can be observed. The three groups of plots from the different study sites are well separated in the ordination space. The magnitude between the control plots and the plots where $100 \%$ of the growing stock was logged can be observed.

\section{Discussion}

Species richness and management are among the most important issues of the scientific research supporting EU's Natura 2000 network (Popescu et al. 2014). Nonetheless, studies focusing on the direct ef-

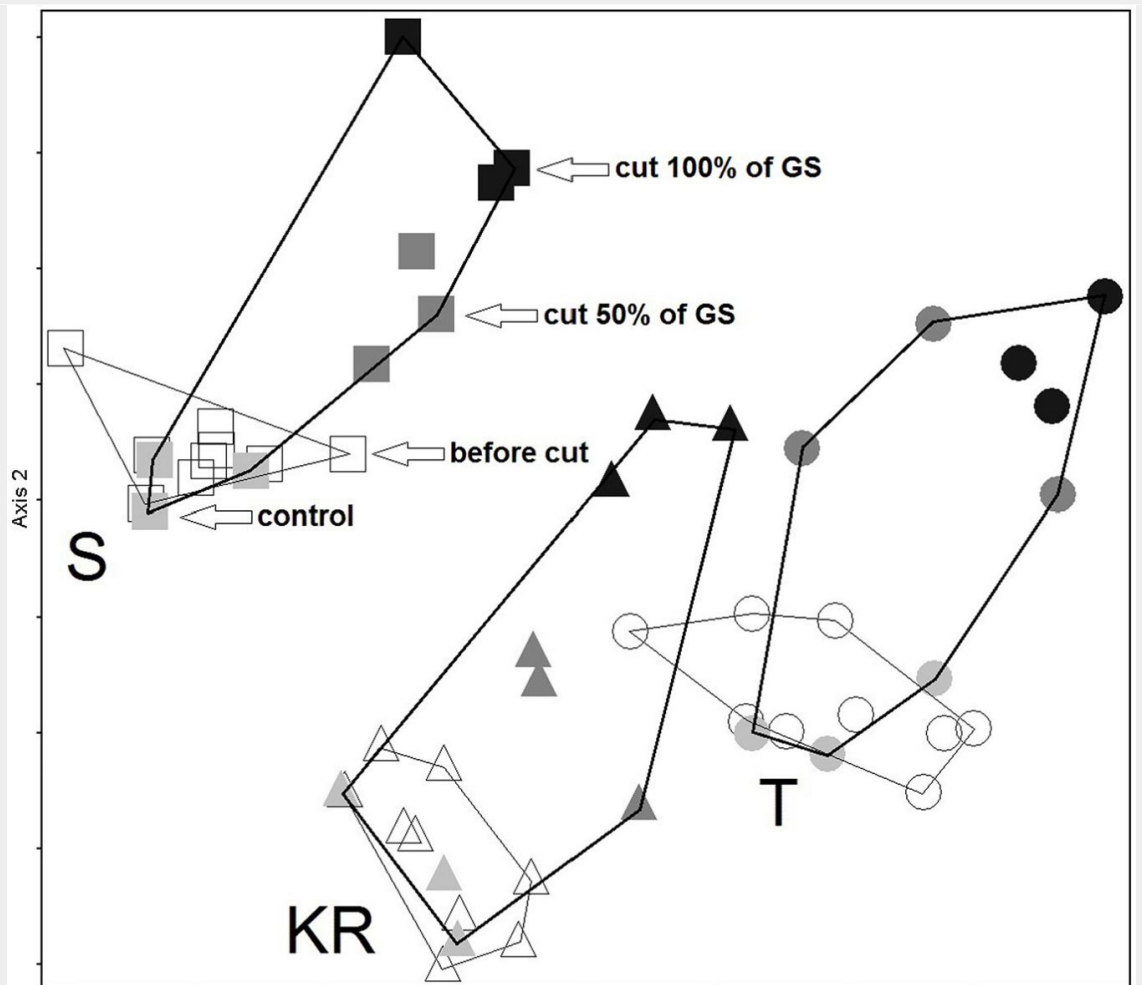

Axis 1
Fig. 3 - DCA ordination of three study sites before and after logging, based on species composition (presence/absence): Kočevski Rog - KR (triangle), Snežnik - S (square) and Trnovo - T (circle). Empty symbols represent the plots before logging (in 2012), while shaded symbols indicate the plots after logging (in 2014). Black symbols represent the plots where $100 \%$ of the growing stock was logged, dark grey symbols indicate those where $50 \%$ of the growing stock was logged, and light grey symbols correspond to control plots with no logging. 
fects of forest management measures on species diversity are scarce. The assessment of species diversity is crucial, being a fundamental property of ecological communities and providing a tool to compare assemblages in time and space (Chiarucci et al. 2008). Following the idea of establishing appropriate management practices for semi-natural lands designated under Natura 2000 (Ostermann 1998) and testing changes in plant species diversity, three sites were selected within the Dinaric firbeech forests belonging to the Natura 2000 habitat type of 91Ko-Illyrian Fagus sylvatica forests. Despite all test sites were selected within the same forest and habitat type, the responses of the plant species to the implementation of silvicultural measures were site specific. The colonization of gaps was rapid, and a substantial turnover of species was observed. Some species disappeared from the gaps, while others newly colonized the areas. Different silvicultural measures resulted in different magnitudes of plant species turnover. With an increasing logging intensity from the control (without logging) to logging 50\% and $100 \%$ of the growing stock, the species turnover increased. The total number of plant species before the silvicultural measures applied was 151, and more than 100 new plant species (mostly early successional species and non-forest plants) appeared in the forest gaps created by the intensive logging. As in the case of central European beech forests (Kelemen et al. 2012), it can be assumed that species with both long-term persistent seed banks and longdistance dispersal abilities were the most successful types in colonizing the gaps. The mean species number per plot, which was almost 49 on average before logging, increased by $49 \%$ in plots with $50 \%$ of the growing stock logged, and by $88 \%$ in plots where $100 \%$ of the growing stock was harvested. More open forest stand conditions, such as those created by gap formation, e.g., $100 \%$ growing stock logging in our study, result in more extreme air and soil temperatures (Heithecker \& Halpern 2006), thus benefiting species that can tolerate such extremes. In the first few years after forest stands are thinned, gap formation may result in an increase in the cover of drought-, fire-, and heat-tolerant species (Neill \& Puettmann 2013). It is likely that such conditions will change over time as the overstory canopies close and the shrub layer species recover from logging operations. Due to a number of influencing factors, including different rates of species colonization and their disappearance, different dynamics of tree recruitment may occur within few years at the three test sites. In particular, extensive cover of graminoids and Rubus species could hamper natural regeneration in forest gaps (Kelemen et al. 2012).

Similarly to temperate beech forests in France (Aubert et al. 2003), it may be concluded that species assemblages during regeneration phases exhibit the highest species richness, and the impacts of thinning and gap formation on understory species groups will likely decrease over time, even though long-term impacts have been documented (Bailey et al. 1998, Lindh \& Muir 2004). In a study of forest regeneration in artificial gaps after canopy opening, D'Oliviera \& Ribas (2011) did not detect significant differences in the parameters of sapling growth and recruitment between gaps and the forest understory twelve years after gap creation.

For biodiversity conservation in the management of Natura 2000 forest areas, it is fundamental to know the resilience of each habitat type and the fragility of the vegetation (Velázquez et al. 2010). This means that it is important to know the rate at which the habitat recovers to its initial status after a perturbation occurs. Habitats containing mainly climax vegetation, such as the studied Illyrian Fagus sylvatica habitats, require more time to return to their original state after natural or anthropogenic disturbances (Velázquez et al. 2010).

In addition to the increased plant diversity and changed functional composition of the vegetation, other benefits of gaps created by logging could be expected. Gap creation in closed forest stands of Dinaric fir-beech forests may improve food availability for wildlife and insect pollinators. Lower overstory densities, thinning and gap creation are associated with the diversification of ecosystem functions and services, specifically the provision of food and habitat for wildlife, as inferred by a higher cover of flowering, fleshy fruit and more palatable plant species (Neill \& Puettmann 2013). Species-rich understory in forest gaps in Dinaric fir-beech forests has high feeding potential for larger herbivores, and consequently, they may reduce the harmful effect of the browsing of young trees in nearby forest stands (Klopčič et al. 2010). It is expected that increased plant diversity also promotes the diversity of other organisms, such as insects and other pollinators (Neill \& Puettmann 2013). Silvicultural measures that create such mosaic forest structures also improve habitat suitability for many bird species, including the endangered capercaillie (Graf et al. 2007). Therefore, to preserve the high level of biodiversity of a wider area, new openings in the forest stand should be made at intervals of several years.

However, the size and position of gaps in the Dinaric fir-beech forest should be carefully adjusted due to sensitive karst terrain with respect to diverse geomorphological features (Kobal et al. 2015), microsite conditions (Cater et al. 2014), drought-related factors (Samaras et al. 2015) and climate change predictions (Kutnar \& Kobler 2011, 2014), especially in the southern exposed limestone slopes, such that forest regeneration and soil productivity are not jeopardized. Although the link between climate change adaption and forest conservation in Natura 2000 areas is mostly an issue for a high-level policy debate (De Koning et al. 2014), the results of this study, which included plots with widely varying microclimatic conditions, could serve as the basis for a better understanding of predicted climate changes in such forest types (Kutnar \& Kobler 2011).

Determining the short-term effects of management on forest biodiversity is the first step for a better understanding of the interaction between management and forest vegetation (Durak 2012) leading to adopt more sustainable long-term management strategies. According to Velázquez et al. (2010), particular emphasis should be placed on the vegetation fragility - the degree of difficulty of recovering from the effects of either a natural or artificial disturbance; the slower and/or more difficult the recovery process, the more vulnerable the habitat type is. To this purpose, monitoring the situation at the study sites in the next five to ten years will provide important information on their resilience.

Management in Natura 2000 forests may contribute to different biodiversity issues, though key biodiversity indexes and indicators of the conservation status need to be defined first at the habitat level. However, it is commonly known that a high level of plant diversity is a major indicator of a favorable conservation status of forest habitats. It is also important that management is aimed at enhancing biodiversity in a wider sense and contributes to biodiversity conservation.

Our findings provide new knowledge to forest managers on the effects of different management practices on plant diversity in the Natura 2000 forests and similar forests where close-to-nature management is applied, as well as the effects on biodiversity in a broader sense.

\section{Acknowledgements}

The research leading to these results received funding from the EU's Life Environment financial instrument of the European LIFE ManFor C.BD Project (LIFEog ENV/IT/ 000078 "Managing forests for multiple purposes: carbon, biodiversity and socioeconomic well-being"). The present article is based on the partial results of a forest experiment of the ManFor C.BD project (http://www.manfor.eu/new/). The preparation of the paper was partly supported by the Research Programmes $\mathrm{P} 4-0107$ and P4-0085, financed by Slovenian Research Agency. We would like to thank Primož Simončič, Milan Kobal, and Marko Kovač (Slovenian Forestry Institute, Ljubljana) for assistance, and many experts of the Slovenian Forest Service for their help in field preparation. The manuscript has undergone revision for English language by Terry $T$. Jackson and American Journal Experts.

\section{References}

ARSO (2014). Climatic maps. Slovenian Environment Agency, Ljubljana, Slovenia. [online] URL: 
http://meteo.arso.gov.si/met/en/climate/maps/ Aubert M, Alard D, Bureau F (2003). Diversity of plant assemblages in managed temperate forests: a case study in Normandy (France). Forest Ecology and Management 75 (1-3): 321-337. - doi: 10.1016/S0378-1127(02)00215-3

Barkman JJ, Doing H, Segal S (1964). Kritische Bemerkungen und Vorschläge zur quantitativen Vegetationsanalyse [Critical comments and suggestions for quantitative vegetation analysis]. Acta botanica neerlandica 13: 394-419. [in German] - doi: 10.1111/j.1438-8677.1964.tboo16 4.x

Bailey JD, Mayrsohn C, Doescher PS, St Pierre E, Tappeiner JC (1998). Understory vegetation in old and young Douglas-fir forests of western Oregon. Forest Ecology and Management 112 (3): 289-302. - doi: 10.1016/S0378-1127(98)0040 8-3

Bouwma IM, Van Apeldoorn R, Kamphorst DA (2010). Current practices in solving multiple use issues of Natura 2000 sites: conflict management strategies and participatory approaches. Alterra, Wageningen, the Netherlands, pp. 77. Birds Directive (1979). Council Directive 79/409/ EEC of 2 April 1979 on the conservation of wild birds. Official Journal L 103, European Council, Brussels, Belgium, pp. 1-18.

Cantarello E, Newton A (2008a). Towards costeffective indicators to maintain Natura 2000 sites in favorable conservation status. Preliminary results from Cansiglio and New Forest. iForest 3: 75-80. - doi: 10.3832/iforo410-0010075 Cantarello E, Newton A (2008b). Identifying cost-effective indicators to assess the conservation status of forested habitats in Natura 2000 sites. Forest Ecology and Management 256: 815-826. - doi: 10.1016/j.foreco.2008.05.031 Canullo R, Starlinger F, Granke O, Fischer R, Aamlid D, Neville P (2011). Assessment of ground vegetation. Manual Part VII.1. In: “ICP Forests. Manual on methods and criteria for harmonized sampling, assessment, monitoring and analysis of the effects of air pollution on forests". UNECE ICP Forests Programme Coordinating Centre, Hamburg, Germany, pp. 19. [online] URL: http://www.icp-forests.org/Manu al.htm

Chiarucci A, Bacaro G, Rocchini D (2008). Quantifying plant species diversity in a Natura 2000 network: old ideas and new proposals. Biological Conservation 141: 2608-2618. - doi: 10.1016/j. biocon.2008.07.024

Cater M, Diaci J, Roženbergar D (2014). Gap size and position influence variable response of Fagus sylvatica L. and Abies alba Mill. Forest Ecology and Management 325: 128-135. - doi: 10.1016/j.foreco.2014.04.001

Dakskobler I (2008). Pregled bukovih rastišč v Sloveniji [A review of beech sites in Slovenia]. Zbornik gozdarstva in lesarstva 87: 3-14. [in Slovenian]

Decocq G, Aubert M, Dupont F, Alard D, Saguez $R$, Wattez-Franger A, De Foucault $B$, DelelisDusollier A, Bardat J (2004). Plant diversity in a managed temperate deciduous forest: understorey response to two silvicultural systems. Journal of Applied Ecology 41: 1065-1079. - doi: 10.1111/j.0021-8901.2004.00960.x

Decocq G, Aubert M, Dupont F, Bardat J, Wattez-Franger A, Saguez R, De Foucault B, Alard
D, Delelis-Dusollier A (2005). Silviculture-driven vegetation change in a European temperate deciduous forest. Annals of Forest Science 62: 313-323. - doi: 10.1051/forest:2005026

De Koning J, Winkel G, Sotirov M, Blondet $M$, Borras L, Ferranti F, Geitzenauer M (2014). Natura 2000 and climate change - polarisation, uncertainty, and pragmatism in discourses on forest conservation and management in Europe. Environmental Science and Policy 39: 129138. - doi: 10.1016/j.envsci.2013.08.010

D’Oliviera MVN, Ribas LA (2011). Forest regeneration in artificial gaps twelve years after canopy opening in Acre State Western Amazon. Forest Ecology and Management 261: 1722-1731. doi: 10.1016/j.foreco.2011.01.020

Durak T (2012). Changes in diversity of the mountain beech forest herb layer as a function of the forest management method. Forest Ecology and Management 276: 154-164. - doi: 10.1016/j. foreco.2012.03.027

EC (2007). Interpretation manual of European Union habitats - EUR28. DG Environment, Brussel, Belgium, pp. 144. [online] URL: http:// ec.europa.eu/environment/nature/legislation/h abitatsdirective/docs/Int_Manual_EU28.pdf

EC (2014). EU forests and forest related policies. European Commission, Brussels, Belgium. [online] URL: http://ec.europa.eu/environment/ forests/home_en.htm

Flamek F (1771). Holz-Schätz oder Überschlagung auch Geometrische Einteilung in die Stallungen oder Jährliche Gehausammentlicher Ternovaner Landesfürstlichen Hoch und Schhwartz Waldungen. Manuscript. [in German]

Gamborg C, Larsen JB (2003). "Back to nature" a sustainable future for forestry? Forest Ecology and Management 179: 559-571. - doi: 10.1016/ S0378-1127(02)00553-4

Graf RF, Bollmann K, Bugmann H, Suter W (2007). Forest and landscape structure as predictors of capercaillie occurrence. The Journal of Wildlife Management 71: 356-365. - doi: 10.2193/2005-629

Habitats Directive (1992). Council Directive 92/ 43/EEC of 21 May 1992 on the conservation of natural habitats and of wild fauna and flora. Official Journal L 206, European Council, Brussels, Belgium, pp. 7-50.

Heithecker TD, Halpern CB (2006). Variation in microclimate associated with dispersed-retention harvests in coniferous forests of western Washington. Forest Ecology and Management 226 (1-3): 60-71. - doi: 10.1016/j.foreco.2006.01. 024

Hill MO, Gauch HG (1980). Detrended correspondence analysis: an improved ordination technique. Vegetatio 42: 47-58. - doi: 10.1007/BFoo 048870

Hufnagel L (1892). Wirtschaftsplan der Betriebsklasse I.: Göttenitzer Gebirge [Management plan of operation class I.: Göttenitzer Mountains]. Kočevje (Gottschee), Slovenia, pp. 228. [in German]

Kelemen K, Mihók B, Gálhidy L, Standovár T (2012). Dynamic response of herbaceous vegetation to gap opening in a Central European beech stand. Silva Fennica 46 (1): 53-65. - doi: 10.14214/sf.65

Klopčič M, Jerina K, Bončina A (2010). Long-term changes of structure and tree species composi- tion in Dinaric uneven-aged forests: are red deer an important factor? European Journal of Forest Research 129: 277-288. - doi: 10.1007/s10 342-009-0325-z

Kobal M, Hladnik D (2009). Stand diversity in the Dinaric fir-beech forests. Zbornik gozdarstva in lesarstva 90: 25-42.

Kobal M, Bertoncelj I, Pirotti F, Dakskobler I, Kutnar $L$ (2015). Using LIDAR data to analyse sinkhole characteristics relevant for understory vegetation under forest cover - case study of a high karst area in the Dinaric mountains. PLoS One 10 (3): e0122070. - doi: 10.1371/journal.p one. 0122070

Kutnar L, Kobler A (2011). Prediction of forest vegetation shift due to different climate-change scenarios in Slovenia. Šumarski list 135 (3-4): 113-126.

Kutnar L, Matijašić D, Pisek R (2011). Conservation status and potential threats to Natura 2000 forest habitats in Slovenia. Šumarski list 135 (5-6): 215-231.

Kutnar L, Kobler A (2014). Possible Impacts of global warming on forest tree species composition in Slovenia. Catena, Advances in GeoEcology 43: 221-230.

Lindenmayer D, Margules C, Botkin D (2000). Indicators of biodiversity for ecologically sustainable forest management. Conservation Biology 14 (4): 941-950. - doi: 10.1046/j.1523-1739.20 00.98533.x

Lindh B, Muir P (2004). Understory vegetation in young Douglas-fir forests: does thinning help restore old-growth composition? Forest Ecology and Management 192 (2-3): 285-296. - doi: 10.1016/j.foreco.2004.01.018

Martinčič A, Wraber $\mathrm{T}$, Jogan $\mathrm{N}$, Podobnik A, Turk B, Vreš B (2007). Mala flora Slovenije Ključ za določanje praprotnic in semenk [Flora of Slovenia - Identification key for ferns and vascular plants]. Tehniška založba Slovenije, Ljubljana, Slovenia, pp. 968. [in Slovenian]

McCune B, Grace JB (2002). Analysis of ecological communities. MjM Software Design, Glenden Beach, Oregon, USA, pp. 12. [online] URL: http://www.researchgate.net/profile/James_Gr ace/publication/216769990

McCune B, Mefford MJ (2011). PC-ORD. Multivariate analysis of ecological data. Version 6.19. MjM Software, Gleneden Beach, Lincoln, OR, USA. [online] URL: http://www.pcord.com/pc ordwin.htm

Neill AR, Puettmann KJ (2013). Managing for adaptive capacity: thinning improves food availability for wildlife and insect pollinators under climate change conditions. Canadian Journal of Forest Research 43 (5): 428-440. - doi: 10.1139/ cjfr-2012-0345

Niemelä J, Young J, Alard D, Askasibar M, Henle K, Johnson R, Kurttila M, Larsson TB, Matouch S, Nowicki P, Paiva R, Portoghesi L, Smulders R, Stevenson A, Tartes U, Watt A (2005). Identifying, managing and monitoring conflicts between forest biodiversity conservation and other human interests in Europe. Forest Policy and Economics 7: 877-890. - doi: 10.1016/j.for pol.2004.04.005

Ostermann OP (1998). The need for management of nature conservation sites designated under Natura 2000. Journal of Applied Ecology 35: 968-973. - doi: 10.1111/j.1365-2664.1998.tbo 
0016.x

Pielou EC (1975). Ecological diversity. Wiley, New York, USA, pp. 165.

Popescu VD, Rozylowicz L, Niculae IM, Cucu AL, Hartel T (2014). Species, habitats, society: an evaluation of research supporting EU's Natura 2000 Network. PLoS One 9 (11): e113648. - doi: 10.1371/journal.pone.0113648

R Core Team (2013). R: a language and environment for statistical computing. R Foundation for Statistical Computing, Vienna, Austria. [online] URL: http://www.r-project.org/

Samaras DA, Gaertner S, Reif A, Theodoropoulos $K$ (2015). Drought effects on the floristic differentiation of Greek fir forests in the mountains of central Greece. iForest (early view): e1-e12. doi: 10.3832/ifor1214-007
Schmidt W (2005). Herb layer species as indicators of biodiversity of managed and unmanaged beech forests. Forest Snow and Landscape Research 79: 111-125. [online] URL: http:// www.wsl.ch/dienstleistungen/publikationen/pd f/6753.pdf

Siry JP, Cubbage FW, Ahmed MR (2005). Sustainable forest management: global trends and opportunities. Forest Policy and Economics 7: 551-561. - doi: 10.1016/j.forpol.2003.09.003

Schollmayer H (1906). Direktiven für die Bestandesaufnahme und die Betriebseinrichtung auf der F.C. Herrschaft Schneeberg [Directives for the inventory and operating equipment at the Schneeberg FC government]. KleinmayrBamberg, Germany and Ljubljana, Slovenia. [in German]
Tutin TG, Heywood VH, Burges NA, Moore DM, Valentine DH, Walters SM, Webb DA (1980). Flora Europaea, Vol. 2-5. Cambridge University Press, Cambridge, MA, USA, pp. 455, 370, 523, 467.

Tutin TG, Burges NA, Chater AO, Edmondson JR, Heywood VH, Moore DM, Valentine DH, Walters SM, Webb DA (1993). Flora Europaea, Vol. 1 - Psilotaceae to Platanaceae ( $2^{\text {nd }}$ edn). Cambridge University Press, Cambridge, MA, USA, pp. 581.

Velázquez J, Tejera R, Hernando A, Núñez MA (2010). Environmental diagnosis: Integrating biodiversity conservation in management of Natura 2000 forest spaces. Journal for Nature Conservation 18: 309-317. - doi: 10.1016/j.jnc.20 10.01.004 